Костенко Ірина Валентинівна кандидат юридичних наук, доцент, Київський політехнічний інститут імені Ігоря Сікорського, вул. Борщагівська, 124, м. Київ, 03056, тел.: (093) 657-38-38, e-mail: kostenko111@gmail.com, https://orcid.org/0000-0002-6974-023X

Царик Олександра В'ячеславівна студентка 1 курсу бакалаврату, групи СП-01 Факультету соціології і права, Національний технічний університет України «Київський політехнічний інститут імені Ігоря Сікорського», вул. Борщагівська, 124, м. Київ, 03056, тел.: (050) 608-6715, e-mail: oleksandra.tsaryk227@gmail.com, https://orcid.org/0000-0003-05936636

Дмитріснко Костянтин Олегович студент 1 курсу бакалаврату, групи СП-01 Факультету соціології і права, Національний технічний університет України «Київський політехнічний інститут імені Ігоря Сікорського», вул. Борщагівська, 124, м. Київ, 03056, тел.: (050) 879-53-22, e-mail: greenorange228@gmail.com, https://orcid.org/0000-0001-7113-8398

\title{
СУЧАСНИЙ СТАН БЕЗОПЛАТНОЇ ПРАВОВОЇ ДОПОМОГИ В УКРАЇ̈I
}

Анотація. Викладений матеріал має мету висвітлити основний сенс та реалії стану безоплатної правової допомоги. Нами була поставлена проблема реалізації права особи на безоплатну правову допомогу, що гарантується як Конституцією України, так і міжнародними договорами, зважаючи на те, що цей інститут почав діяти лише нещодавно в Україні.

Наукова стаття досліджує сучасний стан безоплатної правової допомоги в Україні та виокремлює перспективи подальшого розвитку досліджуваного питання. Основним інструментом написання статті був аналіз та дослідження робіт та публікацій фахівців юридичної галузі. Стаття виконує поставлену мету, а саме аналізує діяльність та прогрес цієї системи, визначає недоліки ії законодавчого регулювання та практичної реалізації, прогнозує подальші шляхи розвитку та вдосконалення існуючої системи.

Основними документами, які допомагали коректувати та деталізувати написання наукової статті були: Конституція України, Закон України «Про безоплатну правову допомогу» від 02.06.2011 року № 3460-V (у редакції від 18.07.2020) та інші похідні чи певним чином пов'язані документи. Було визначено та проаналізовано хто $є$ суб'єктами надання безоплатної первинної правової допомоги відповідно до ЗУ «Про безоплатну правову допомогу» (ст.9), та вторинної правової допомоги визначив документи, які регулюють якість надання визначених нормативно-правовими актами послуг та чітку 
реалізацію своїх функцій.

Важливою частиною статті є аналіз європейської практики безоплатної правової допомоги, що, безумовно, грає роль при визначенні стану цієї системи в сучасних реаліях нашої держави. Висновок узагальнює весь викладений вище матеріал та пояснює необхідність наявності такої системи, які відбулись прогресивні зміни за останні роки, а також, які мінуси i недоліки, що заважають системі працювати наповну 3 використанням усіх можливих ресурсів.

Ключові слова: безоплатна правова допомога, суб'єкти безоплатної правової допомоги, вторинна безоплатна правова допомога, права та обов’язки, закон України, внутрішньо переміщені особи.

Kostenko Iryna Valentynivna Candidate of Law, Associate Professor, Igor Sikorsky Kyiv Polytechnic Institute, Borshchahivska St., 124, Kyiv, 03056, tel.: (093) 657-38-38, e-mail: kostenko111@gmail.com, https://orcid.org/0000-00026974-023X.

Tsaryk Oleksandra Vyacheslavivna 1st year undergraduate student, group SP-01 of the Faculty of Sociology and Law, National Technical University of Ukraine «Igor Sikorsky Kyiv Polytechnic Institute», Borshchahivska St., 124, Kyiv, 03056, tel.: (050) 608-67-15, e-mail: oleksandra.tsaryk227@ gmail.com.

Dmytrienko Kostiantyn Olehovych 1st year undergraduate student, group SP-01 of the Faculty of Sociology and Law, National Technical University of Ukraine «Igor Sikorsky Kyiv Polytechnic Institute», Borshchahivska St., 124, Kyiv, 03056,tel.: (050) 879-53-22, e-mail: greenorange228@gmail.com.

\section{THE CURRENT STATE OF FREE LEGAL AID IN UKRAINE}

Abstract. The above material aims to highlight the basic meaning and realities of the state of free legal aid. We posed the problem of exercising the right of a person to free legal aid, which is guaranteed by both the Constitution of Ukraine and international treaties, given that this institution has only recently begun to operate in Ukraine.

The scientific article examines the current state of free legal aid in Ukraine and identifies prospects for further development of the research issue. The main tool for writing the article was the analysis and research of works and publications of legal professionals. The article fulfils the set goal, namely, analyses the activities and progress of this system, identifies the shortcomings of its legislative regulation and practical implementation, predicts further ways to develop and improve the existing system.

The main documents that helped to correct and detail the writing of the scientific article were: the Constitution of Ukraine, the Law of Ukraine "On Free Legal Aid" dated 02.06.2011 № 3460-V (as amended on 18.07.2020) and other derivatives or in some way related documents. It was identified and analysed who 
are the subjects of free primary legal aid in accordance with the Law "On Free Legal Aid" (Article 9), and secondary legal aid identified documents governing the quality of services specified by regulations and the clear implementation of their functions.

An important part of the article is the analysis of European practice of free legal aid, which, of course, plays a role in determining the state of this system in the modern realities of our state. The conclusion summarizes all the above material and explains the need for such a system, what progressive changes have taken place in recent years, as well as what are the disadvantages and shortcomings that prevent the system to work fully using all possible resources.

Keywords. Free legal aid, subjects of free legal aid, secondary free legal aid, rights and responsibilities, the law of Ukraine, internally displaced persons.

Постановка проблеми. Реалізація права особи на правову допомогу є основоположним моментом, що гарантується як Конституцією України, так і міжнародними договорами. За для цього було створену відповідну систему гарантій на забезпечення правової допомоги особам, що прослідковується у наступних моментах: захист прав людини на всіх рівнях, виключення дискримінації як на майновому рівні, так і на релігійному підтексті, зокрема. Це все стало вагомим важелем за для створення інституту правової допомоги в Україні. Зважаючи на те, що цей інститут почав діяти лише нещодавно, то все ще немає тієї ефективності, якої від нього чекають (у відповідності до європейських стандартів). Тому вважаємо за потрібне дослідити сучасний стан безоплатної правової допомоги в Україні та виокремити перспективи подальшого розвитку досліджуваного питання.

Аналіз останніх досліджень i публікацій. Дослідженням стану безоплатної правової допомоги в Україні в цілому займалися багато фахівців, серед них слів виокремити: Е.В. Магаррамлі, І.Д. Козьяков, В.С. Личко, А.В. Іванцова, А.Г. Гаркуша, В.М. Ісакова, Л.А. Литовченко та ін.

Метою статті $\epsilon$ аналіз діяльності стану безоплатної правової допомоги, визначення недоліків іiі законодавчого регулювання та практичної реалізації, прогнозування подальших шляхів розвитку та вдосконалення існуючої системи.

Виклад основного матеріалу. Конституція України проголошує, що право людини на правову допомогу $\epsilon$ одним iз основоположних конституційних прав кожної людини [1]. Тому важливо було створити ефективну діючу систему забезпечення правової допомоги для осіб, що іiі дійсно потребують. Не можна не згодитись 3 А.Г. Гаркушою, що у своїй праці зазначає «актуальним постає захист прав людини, підвищення правосвідомості та правопросвітництво як елемент спроможності соціально вразливих груп населення відстоювати свої права та законні інтереси» [2, с.16]. Закономірним було створення на основі конституційних засад, що прозвучали до цього, відповідного нормативно-правового акту, який би регулював питання забезпечення правової допомоги. Таким документом слугує Закон України (далі ЗУ) «Про безоплатну правову допомогу» від 
02.06.2011 року № 3460-V ( у редакції від 18.07.2020) [3]. Даний закон визначає змістову частину права на безоплатну правову допомогу, яким чином регулюється дане право, яким чином надається безоплатна правова допомога, а також яким чином держава може гарантувати право на безоплатну правову допомогу.

Виходячи із ноти закону, бачимо, що «безоплатна правова допомога - це правова допомога, що гарантується державою та повністю або частково надається за рахунок коштів Державного бюджету України, місцевих бюджетів та інших джерел» [3]. Поміж цього законом зазначається, що існує первинна та вторинна правова допомога. Щодо самої структури безоплатної первинної правової допомоги. Структуру становлять: суб'єкти надання послуг, суб'єкти права на послуги, надання правових послуг.

Проаналізувавши суб'єктів надання безоплатної первинної правової допомоги відповідно до ЗУ «Про безоплатну правову допомогу» (ст.9) суб'єктами є: органи виконавчої влади, органи місцевого самоврядування, фізичні та юридичні особи приватного права, спеціалізовані установи, центри надання безоплатної правової вторинної допомоги [3].

У свою чергу суб'єктами вторинної правової допомоги виступають: центри надання безоплатної вторинної правової допомоги, адвокати, включені до Реєстру адвокатів, які надають безоплатну вторинну правову допомогу [3]. Слід зазначити, що питання вторинної правової допомоги окрім основного закону регулюється також Наказом Міністерства юстиції України «Про затвердження Стандартів якості надання безоплатної вторинної правової допомоги у цивільному, адміністративному процесах та представництва у кримінальному процесі» від 21.12.2017 № 4125/5 [4].

Важливим питанням $є$ забезпечення досліджуваного права на світовому рівні, адже Україна пролонгувала низку договорів 3 даного питання. Одним 3 таких договорів є договір у межах стандартів Організації об'єднаних націй (далі $\mathrm{OOH}$ ), що проголошує право на правову допомогу. Так, в Основних положеннях про роль адвокатів, прийнятих VIII Конгресом ООН по запобіганню злочинам (1990р.), під правом особи на правову (юридичну) допомогу розуміється право:

- на звернення за допомогою до адвоката за власним вибором для підтвердження своїх прав і для захисту на всіх стадіях кримінальної процедури (п. 1);

- на юридичну допомогу бідних і незаможних людей (п. 3);

- на консультацію про права й обов'язки з роз'ясненням принципів роботи правової системи, оскільки вони стосуються прав та обов'язків клієнта (пп. а) п. 13);

- на отримання допомоги клієнтом будь-яким законним способом і на вчинення адвокатом правових дій для захисту інтересів клієнта (пп. б) п. 13);

- на отримання допомоги в судах, трибуналах та адміністративних органах (пп. в) п. 13) [5, с.41].

Проаналізувавши сучасний стан правової допомоги бачимо, що станом на 2020-2021 роки відбулися наступні зміни: 
- утворено Наглядову раду Координаційного центру наказ Міністерства Юстиції від 17.03.2020 № 662/7 [6];

- розширено категорії осіб, які мають право на безоплатну вторинну правову допомогу - таке право отримали викривачі корупції та особи, які претендують на статус осіб без громадянства;

- поширено на всю територію України дію пілотного проєкту з відновного правосуддя для неповнолітніх (спільний наказ Генпрокуратури та Мін'юсту від 17.04.2020 № 1473/5/194 «Про внесення змін до наказу Міністерства юстиції України, Генеральної прокуратури України від 21 січня 2019 року № 172/5/10», зареєстрований у Мін'юсті 21.04.2020 за № 360/34643 [7]);

- розпочато участь у реалізації проєкту «Прискорення приватних інвестицій у сільське господарство України» (Угода про позику між Україною та Міжнародним банком реконструкції та розвитку від 27.08.2019 № 8973-UA щодо проєкту «Програма прискорення приватних інвестицій у сільське господарство України»);

- розширено сервіси дистанційного надання правової інформації та роз'яснень із правових питань (розроблено мобільний застосунок «Безоплатна правова допомога», отриманий від Програми розвитку ООН застосунок «Твоє право», запроваджено чати у Telegram та Viber 3 автоматизованим сервісом опрацювання усіх звернень) $[8$, с.3].

На сьогодні ми бачимо ці зміни не лише «на папері», але й у режимі реального часу. Про це свідчать і відгуки членів європейського співтовариства. Так, Ганна Христова, керівниця проєкту Ради Європи «Внутрішнє переміщення в Україні: розробка тривалих рішень» зазначає, що «Експерти Ради Європи підтверджують, що на сьогодні система Безоплатної правової допомоги (далі БПД) в Україні належить до однієї 3 найбільш передових систем безоплатної правової допомоги серед усіх 47 країн-членів Ради Європи. Надважливо, що система безоплатної правової допомоги упроваджує стандарти Ради Європи, передовсім практику Європейського суду $з$ прав людини, при наданні правової допомоги».

Проаналізувавши статистичні дані за 2020 рік бачимо, що позитивні досягнення спостерігались як в регіональних так і місцевих центрах. Так, в регіональних центрах протягом 2020 року було видано 87276 доручень адвокатам для надання безоплатної вторинної правової допомоги (далі БВПД), $з$ яких 19199 - для здійснення захисту затриманих осіб в кримінальному процесуальному порядку, 45731 — для здійснення захисту за призначенням, 4851 - для здійснення захисту осіб, затриманих в адміністративному порядку, 9187 - для участі у проведенні окремої процесуальної дії. Крім того, видано 3862 - доручення для захисту при застосуванні примусових заходів медичного характеру, 3064 - для надання БВПД при вирішенні судом питань під час виконання вироків, а також 1217 - для надання БВПД засудженим до позбавлення волі особам, 165 надання БВПД під час екстрадиції осіб. У 94,6\% випадків видані доручення були виконані, лише в 5,4\% (4 955) клієнти відмовилися від правової допомоги адвокатів, залучених для надання БВПД. У 99,5\% випадків адвокат 
прибував до затриманої особи у встановлений законодавством строк, тобто не пізніше ніж через одну годину після видання доручення на надання БВПД та не пізніше двох годин із моменту інформування про затримання. А у свою чергу на місцевому рівні у 2020 році у 90\% (510 118) випадків клієнти зверталися по правові консультації та роз'яснення, інші види БППД. Зокрема, 209158 випадків надання консультацій, 299738 - надання правової інформації, 20480 - складення заяв та скарг, 1865 - забезпечення доступу до медіації, 49090 - забезпечення доступу до БВПД. Найбільше звернень по БППД у Дніпропетровській, Запорізькій та Київській областях, найменше у Чернівецькій і Закарпатській областях та місті Києві. У 2020 році прийнято 58813 рішень про надання клієнтам БВПД. 3 них у 27061 випадку надавати БВПД доручено адвокатам, у 30032 - штатним працівникам системи БПД [8, с.6].

Окрім цього, було розроблено багато ініціатив, серед яких було реалізовано проєкт програми «Прискорення приватних інвестицій у сільське господарство України», який реалізується відповідно до Угоди про позику між Україною та Міжнародним банком реконструкції та розвитку, укладеної у 2019 році. Після здійснення Україною внутрішньодержавних процедур угода про позику у травні 2020 року набрала чинності. У межах проєкту перед системою БПД стоять два основні завдання:

- посилення захисту прав громадян у сфері земельних відносин шляхом надання безоплатної первинної та вторинної правової допомоги;

- посилення правової спроможності громадян та громад у сфері земельних відносин шляхом покращення правової обізнаності у результаті проведення правопросвітницьких заходів.

У 2020 році система БПД реалізовувала проєкт у всіх регіонах, при цьому оцінювання результативних показників проводилося у 10 пілотних областях - Волинській, Дніпропетровській, Київській, Кіровоградській, Львівській, Одеській, Полтавській, Рівненській, Харківській, Чернігівській. У 2021 році територія оцінювання стану впровадження проєкту розширена до 20 областей [8, с.8].

Також варто зазначити, що було приділено велику увагу правовим проблеми окремих категорій громадян. Розберемо яких самих категорій і які зміни відбулися.

Малозабезпечені особи. Малозабезпечені особи мають право на БВПД, якщо їхній середньомісячний дохід не перевищує двох розмірів прожиткового мінімуму, розрахованого та затвердженого відповідно до закону для осіб, які належать до основних соціальних і демографічних груп населення. Такі клієнти звертаються по БВПД найчастіше. У 2020 році від них надійшло 30313 (51,5\%) звернень по БВПД. Понад 35\% цих звернень (10 861) від осіб віком понад 60 років.

Люди з інвалідністю. Люди з інвалідністю мають право на БВПД, якщо отримують пенсію або допомогу, що призначається замість пенсії, у розмірі, який не перевищує двох прожиткових мінімумів для непрацездатних осіб. У 2020 році 8167 (13,9\%) звернень по БВПД надійшло від осіб з інвалідністю. 
Внутрішньо переміщені особи. Внутрішньо переміщені особи (далі ВПО) мають право на БВПД. Крім того, особи, які звернулися із заявою про взяття їх на облік як ВПО, мають право на БВПД з питань, пов'язаних 3 отриманням довідки про взяття на облік як ВПО. Упродовж 2020 року від ВПО надійшло 4392 звернення про надання БВПД (7,4\%).

Постраждалі від домашнього насильства. Із січня 2018 року особи, які постраждали від домашнього насильства або насильства за ознакою статі, набули права на всі види БВПД. Водночас, попри зростання відсотка звернень до системи БПД порівняно з попереднім роком, загалом таких звернень небагато. За 2020 рік надійшло 1177 звернень по БВПД від осіб, які постраждали від домашнього насильства, з них 1123 (95\%) від жінок та 54 (5\%) від чоловіків.

Біженці та особи без громадянства. Право на БВПД мають особи, які звернулися із заявою про визнання біженцем або особою, яка потребує додаткового захисту в Україні, до прийняття остаточного рішення за заявою, а також іноземці та особи без громадянства, затримані з метою ідентифікації та забезпечення примусового видворення, з моменту затримання. 318 жовтня 2020 року право на БВПД набули особи, які звернулися із заявою про визнання особою без громадянства. У 2020 році зареєстровано 290 звернень $(0,5 \%)$ від осіб, які звернулися із заявою про визнання їх біженцями, та 67 $(0,1 \%)$ від осіб, які звернулися із заявою про визнання їх особою без громадянства.

Національні меншини. Одним із напрямів роботи системи БПД $є$ правовий захист національних меншин. Представники національних меншин не є суб'єктами права на БВПД. Такі особи мають можливість скористатися цим видом правової допомоги лише в разі належності їх до інших категорій, зокрема малозабезпечені [8, с.24-30].

Окрім зазначених перемог все ще існує багато прогалин на які не можна не звернути увагу, серед них:

- наявність проблем щодо нерівномірного розподілу доручень між адвокатами.

Система винагороди адвокатів БВПД: рекомендовано спростити чинну дуже деталізовану систему оплати, яка, як зазначено у звіті за результатами оцінювання, забирає багато часу та є досить обтяжливою для органів БВПД та адвокатів. Для європейських країн непоодинокою $\epsilon$ тенденція застосування системи фіксованих платежів.

- контроль та забезпечення якості: у Європі дедалі більшу увагу приділяють забезпеченню належної якості правової допомоги;

- проблематика надання правової допомоги засудженим особам.

В Україні для цього наявна відповідна нормативна база. Проте рекомендовано посилити механізми контролю якості, зокрема, шляхом розширення норм, які закріплюють стандарти якості правової допомоги невирішеність питання реалізації права на безоплатну правову допомогу засуджених. У багатьох випадках для отримання безоплатної вторинної правової допомоги необхідно зібрати необхідні документи, що 
підтверджують належність особи до певної категорії суб'єктів, що підпадають під дію закону. Тобто засуджений повинен документально підтвердити, що його засудили в Україні за злочин, що його покарання набрало чинності, що його засуджено до таких покарань, як ув'язнення або тримання під вартою в дисциплінарному батальйоні військовослужбовців або обмеження волі. Недостатньо надати копію вироку для підтвердження статусу засудженої особи, оскільки документи до центрів забезпечення безоплатної правової допомоги мають бути подані в оригіналі або в належним чином завіреній копії [9, с.164].

- питання суб'єктів надання безоплатної правової допомоги.

Як заявляє Ніна Рогатинська «зокрема окрема ПБПД, не може забезпечити надання безоплатної правової допомоги, адже для цього визначені суб'єкти повинні мати комплекс законодавчо встановлених прав i обов'язків, які зможуть забезпечити цими суб'єктами виконання поставлених перед ними завдань. Відповідно перспективний напрям подальших наукових пошуків становить окреслення та розкриття змісту компетенції суб'єктів надання безоплатної правової допомоги» [10, с.183].

Висновки. Впровадження системи безоплатної правової допомоги $\epsilon$ важливим чинником для побудови правової держави із фундаментальними соціальними цінностями. Здійснення надання професійної правничої допомоги соціально вразливим групам населення є започаткування переходу від укоріненої в свідомості громадян радянської системи правосуддя, яка носила більш каральний, аніж виправдувальний характер.

Попри те, що за останні роки було здійснено величезний прорив у сфері забезпечення відповідним особам безоплатної правової допомоги, ми можемо спостерігати наявність недоліків, що все-таки відчуваються у правовому законодавстві і тому, звичайно, закликаємо відповідні уповноважені органи звернути на цей факт увагу.

\section{Jimepamypa:}

1. Конституція України: Закон від 28.06.1996 № 254к/96-BP URL: https://zakon.rada.gov.ua/laws/show/254к/96-вр\#Text.

2. Гаркуша, А. Г. Деякі аспекти надання безоплатної правової допомоги в Україні. Форум Права, 55(2). 2019, с. 15-22.

3. Закон України «Про безоплатну правову допомогу» від 02.06 .2011 року № 3460 V URL: https://zakon.rada.gov.ua/laws/show/3460-17\#Text .

4. Наказ Міністерства юстиції України «Про затвердження Стандартів якості надання безоплатної вторинної правової допомоги у цивільному, адміністративному процесах та представництва у кримінальному процесі»: від 21.12.2017 № 4125/5 URL: https://zakon.rada.gov.ua/laws/show/z1554-17\#Text.

5. Іванцова А.В. Поняття безоплатної правової допомоги в україні та за кордоном. Часопис Академії адвокатури України № 3. 2015. С.41-45.

6. Наказ Міністерства юстиції України «Про затвердження Положення про Наглядову раду Координаційного центру з надання правової допомоги» від 14.08.2019 № 2551/5 URL: https://zakon.rada.gov.ua/laws/show/z0932-19\#Text. 
7. Спільний наказ Генпрокуратури та Міністерства юстиції України «Про внесення змін до наказу Міністерства юстиції України, Генеральної прокуратури України від 21 січня 2019 року № 172/5/10» від 17.04.2020 № 1473/5/194 (зареєстрований у Мін'юсті 21.04.2020 за № 360/34643) URL: https://zakon.rada.gov.ua/laws/show/z036020\#Text

8. Звіт за 2020 рік Міністерства Юстицій України «Безоплатна правова допомога» URL: https://www.legalaid.gov.ua/publichna-informatsiya/bezoplatna-pravova-dopomoga-2020/

9. Магаррамлі Е. В. Суб'єкти надання безоплатної первинної правової допомоги:система та їх характеристика. Право і суспільство. №2 частина 2. 2020 с.178184.

10. Рогатинська Н. Розбудова системи безоплатної правової допомоги в Україні. Актуальні проблеми правознавства. №1 (13). 2018. с.164.

\section{References:}

1. Konstytutsiia Ukrainy: Zakon vid 28.06.1996 № 254k/96-VR URL: https://zakon.rada.gov.ua/laws/show/254k/96-vr\#Text [in Ukrainian].

2. Harkusha, A. H. (2019). Deiaki aspekty nadannia bezoplatnoi pravovoi dopomohy v Ukraini [Some aspects of free legal aid in Ukraine]. Forum Prava, 55(2), 15-22 [in Ukrainian].

3. Zakon Ukrainy «Pro bezoplatnu pravovu dopomohu» vid 02.06.2011 roku № 3460-V URL: https://zakon.rada.gov.ua/laws/show/3460-17\#Text [in Ukrainian].

4. Nakaz Ministerstva yustytsii Ukrainy «Pro zatverdzhennia Standartiv yakosti nadannia bezoplatnoi vtorynnoi pravovoi dopomohy u tsyvilnomu, administratyvnomu protsesakh ta predstavnytstva u kryminalnomu protsesi»: vid 21.12.2017 № 4125/5 URL: https://zakon.rada.gov.ua/laws/show/z1554-17\#Text [in Ukrainian].

5. Ivantsova A.V. (2015). Poniattia bezoplatnoi pravovoi dopomohy v ukraini ta za kordonom [The concept of free legal aid in Ukraine and abroad]. Chasopys Akademii advokatury Ukrainy, 3, 41 - 45 [in Ukrainian].

6. Nakaz Ministerstva yustytsii Ukrainy «Pro zatverdzhennia Polozhennia pro Nahliadovu radu Koordynatsiinoho tsentru z nadannia pravovoi dopomohy» vid 14.08.2019 № 2551/5 URL: https://zakon.rada.gov.ua/laws/show/z0932-19\#Text [in Ukrainian].

7. Spilnyi nakaz Henprokuratury ta Ministerstva yustytsii Ukrainy «Pro vnesennia zmin do nakazu Ministerstva yustytsii Ukrainy, Heneralnoi prokuratury Ukrainy vid 21 sichnia 2019 roku № 172/5/10» vid 17.04.2020 № 1473/5/194 (zareiestrovanyi u Min’iusti 21.04.2020 za № 360/34643) URL: https://zakon.rada.gov.ua/laws/show/z0360-20\#Text [in Ukrainian].

8. Zvit za 2020 rik Ministerstva Yustytsii Ukrainy «Bezoplatna pravova dopomoha» URL: https://www.legalaid.gov.ua/publichna-informatsiya/bezoplatna-pravova-dopomoga-2020/ [in Ukrainian].

9. Maharramli E. V. (2020). Sub'iekty nadannia bezoplatnoi pervynnoi pravovoi dopomohy: systema ta yikh kharakterystyka [Subjects of free primary legal aid: system and their characteristics]. Pravo i suspilstvo, 2 chastyna 2, 178-184 [in Ukrainian].

10. Rohatynska N. (2018). Rozbudova systemy bezoplatnoi pravovoi dopomohy v Ukraini [Development of a free legal aid system in Ukraine]. Aktualni problemy pravoznavstva. 1 (13), 164 [in Ukrainian]. 